\title{
Accounting Quality and Firm-level Capital Investment
}

\author{
Gary Biddle \\ and \\ Gilles Hilary \\ biddle@ust.hk \\ acgh@ust.hk
}

\author{
Department of Accounting \\ Hong Kong University of Science and Technology \\ Clear Water Bay, Kowloon \\ Hong Kong
}

Forthcoming, The Accounting Review, October 2006

We are grateful for the research assistance of Fenny Cheng and for helpful comments received from two anonymous reviewers, Mary Barth, Jean de Bettignies, Donal Byard, Songnian Chen, Dan Dhaliwal (the editor), Clive Lennox, Steve Orpurt, Douglas Skinner, Guochang Zhang and workshop participants at Baruch College, Cass Business School, Hong Kong University of Science and Technology, London School of Economics, Singapore Management University, University of British Columbia, and Waseda University. Biddle and Hilary thank the University Grants Committee of Hong Kong for financial support (HKUST6435/05H). 


\title{
Accounting Quality and Firm-level Capital Investment
}

\begin{abstract}
This study examines how accounting quality relates to firm-level capital investment efficiency. Our first hypothesis is that higher quality accounting enhances investment efficiency by reducing information asymmetry between managers and outside suppliers of capital. Our second hypothesis is that this effect should be stronger in economies where financing is largely provided through arm's-length transactions compared with countries where creditors supply more capital. Our results are consistent with these hypotheses both across and within countries. They are robust to alternative econometric specifications, different measures of accounting quality and investment-cash flow sensitivity, and numerous control variables.
\end{abstract}

Keywords: Accounting Quality, Capital Investment, Corporate Governance 


\section{Accounting Quality and Firm-level Capital Investment}

\section{Introduction}

A significant body of prior literature examines relations between accounting quality and financial market characteristics, yet little prior research exists that analyzes the effects of accounting quality on investment. Here, we examine how accounting quality relates to firm-level capital investment efficiency, a key determinant of economic productivity. Our focus on investment in productive assets complements and extends findings on how accounting relates to public financial markets' operating characteristics. For example, Bhattacharya et al. [2003] find that accounting opacity is associated with a higher cost of publicly traded equity capital across 34 countries. However, institutional features may be related to firm-level capital investment differently than to equity market operations. For instance, private financing from banks in Germany (e.g., Gorton and Schmid [2000]), keiretsu in Japan (e.g., Hoshi et al. [1991]), and families in East Asia (e.g., Claessens et al. [2000]) may obviate or alter the effects of institutional features from their operational roles in public equity markets. Hence, how accounting quality affects the efficiency of firm-level capital investments remains an open question of fundamental importance.

In the neoclassical setting, managers (i.e., firms) endowed with capital invest until the marginal return is zero, allowing for adjustment costs (e.g., Tobin [1969], Hayashi [1982]). In this baseline setting, we should not observe an association between internally generated cash flows and investment. But several frictions contradict this efficient result. One is capital rationing, which is generated by information asymmetry between managers 
and investors. Since at least Myers [1984], it has been shown that if managers can exploit private information to issue securities at inflated prices, investors rationally withhold capital. A resulting reliance on internal funding increases the sensitivity of investments to cash. A second friction arises from agency problems, when managers pursue perquisite consumption and "empire building" rather than returning excess cash to investors (e.g., Jensen [1986], Blanchard et al. [1994]). ${ }^{1}$ This behavior also may increase the sensitivity of investments to cash flows but, in this case, the sensitivity is due to an excess of cash.

Certain institutional features may serve to mitigate these deviations from the optimal investment policy. For example, Rajan and Zingales [2000] observe that "to function properly, a financial system requires clear laws and rapid enforcement, an accounting and disclosure system that promotes transparency and a regulatory infrastructure that protects consumers and controls risk." Transparent accounting should reduce both adverse selection (i.e., the tendency to issue securities at an inflated price) and moral hazard (i.e., perquisite consumption using assets in place) by improving contracting and monitoring. ${ }^{2}$ Thus, higher quality accounting may serve to enhance investment efficiency by mitigating these frictions.

We examine this hypothesis by considering the effects of differences in accounting quality both at the country level and at the firm level within countries. To do so, we first estimate investment-cash flow sensitivities for firms from 34 countries. We then consider how the average investment-cash flow sensitivity across countries varies with accounting quality. We measure accounting quality using three proxies for earnings quality described by Bhattacharya et al. [2003], as well as a measure of accounting

\footnotetext{
${ }^{1}$ Note that the existence of the agency problem ex post may lead to rationing of capital ex ante.

${ }^{2}$ See Healy and Palepu [2001] for a review.
} 
timeliness from Bushman et al. [2004]. We also are careful to control for the confounding effects of other institutional features, such as disclosure quality (CIFAR index), legal origin, creditor and shareholder rights, judicial efficiency, and economic conditions (e.g., the degree of economic development). We find that higher accounting quality is associated with lower investment-cash flow sensitivity. We also find that other institutional features, particularly creditor rights and disclosure quality, play a similar but incremental role. These results persist after allowing for the possibility that operating cash flows convey additional information about short-term profitability (e.g., Alti [2003]).

Having established that differences in accounting quality are associated with differences in the efficiency of capital investments across countries, we then examine how sources of financing (debt versus equity) affect this relation. A priori, we expect accounting quality to play a stronger role in economies where financing is largely provided through arm's-length transactions, for example, where stock exchanges are the dominant sources of capital, since here, investment decisions rely more heavily on public accounting disclosures. On the other hand, in economies where creditors play a more dominant role, banks may be able to obtain information through private channels (mitigating adverse selection problems), and they may be in a better position to directly monitor managers once capital is supplied (mitigating moral hazard). Thus, in creditdominated economies, the quality of publicly disclosed accounting information should be less influential in decisions to supply capital than in public equity-dominated economies. Therefore, we should observe a smaller effect on capital investment decisions when 
accounting quality is improved in credit-dominated economies than in public equitydominated economies.

We test this hypothesis in two ways. Initially, we regress cash flow sensitivity on accounting quality in our cross-country sample, partitioning observations in two groups based on the prevalence of public equity versus debt financing. We find that higher accounting quality is associated with lower investment-cash flow sensitivity in economies that depend more on public equity financing compared with those more reliant on debt financing. Then, we examine the effect of accounting quality on investment efficiency at the firm level in two selected countries. We do this for several reasons. First, it allows us to determine whether accounting quality operates similarly across and within countries. Second, it helps us to control for certain differences in characteristics across countries that could affect our cross-country results, such as correlations between accounting quality, legal origins, creditor rights and administrative efficiency. Finally, as explained below, this firm-level analysis allows us to address certain econometric issues.

In our within-country tests, we examine two polar cases - the US and Japan - for several reasons. First, they are the two largest economies in the world with abundant external financing available to firms. Second, they provide large and diversified firm samples with long time-series data that enable us to estimate firm-specific parameters with a reasonable level of confidence. Comparable datasets are generally not available for other countries. However, the US and Japan differ along one important dimension. Public equity capital plays a much more dominant role as a source of firm financing in the US than in Japan. Thus, we expect accounting quality to play a more important role in the largely arm's-length transactions in the US. On the other hand, Japanese suppliers of 
capital, such as keiretsu and banks, have non-public sources of information and thus the quality of public accounting disclosures may be less relevant to their decisions to supply capital. Our results are consistent with these predictions. Accounting quality matters both statistically and economically in the US where higher quality accounting is associated with lower investment-cash flow sensitivity, but we do not observe such a relation in Japan.

Our findings contribute in at least two ways to the existing literature. First, they provide empirical evidence that accounting and other institutional features relate to the economic fundamentals of firm-level capital investment efficiency. In particular, accounting quality is shown to reduce frictions in the investment process. We find that this effect exists both across countries and within countries, even in the most liquid capital market, the US. Second, our findings confirm that this effect is stronger in economies where public equity capital plays a greater role in capital investment financing compared with countries dominated by debt financing. This effect is observed in both our cross- and within-country tests.

We proceed as follows. Section 2 reviews related research. Section 3 develops our hypotheses. Section 4 describes our tests for relations between accounting quality and investment-cash flow sensitivity. Section 5 presents our findings. Section 6 concludes the paper.

\section{Related Research}

Economists have long studied how financial frictions affect investment decisions and economic growth. This literature is too extensive to review comprehensively here, 
though we discuss selected results in Section 4.1 below. ${ }^{3}$ More recently, scholars in accounting, finance and law have focused their attention on the effects of institutional features (such as legal structure or judicial enforcement) on market frictions and their consequences for capital investment. For example, Bhattacharya et al. [2003] have shown that the cost of publicly traded equity across 34 countries is related to three different measures of earnings transparency. Francis et al. [2005] provide international evidence that dependence on external financing creates incentives for firms to undertake higher levels of voluntary accounting disclosure. However, the implication of these findings for firm-level investment is not straightforward. If equity financing were the only source of capital, frictions in equity financing would probably lead to frictions in capital investing. However, firms can access multiple sources of financing. Thus, if one channel is inefficient (e.g., public equity financing), other sources such as debt, private financing, state subsidies, and intra-group capital transfers, for example, can substitute. In equilibrium, there may not be any differences in investment efficiency at the firm level, but simply cross-sectional differences in financing patterns. Consistent with this view, Demirguc-Kunt and Maksimovic [2002] find no evidence that a country's relative reliance on bank versus stock market financing affects firms' access to external financing.

Other studies have considered relations between institutional features and capital investment at the industry level. For example, Wurgler [2000] measures cross-country capital allocation efficiency by industry-level elasticity of investment with respect to value added. He finds this measure to be positively related to the amount of firm-specific

\footnotetext{
${ }^{3}$ See also Hubbard [1998] for a review and representative studies by Bagehot [1873], King and Levine [1993], Rousseau and Wachtel [1998] and Beck, Levine and Loayza [2000].
} 
information available in domestic stock markets when measured by synchronicity, positively related to minority shareholder rights, and negatively related to state ownership. Rajan and Zingales [1998] show that industry growth is positively related to a financial development index.

Our paper advances the existing literature in several ways. First, instead of considering the effect of institutional features on industry growth (e.g., Rajan and Zingales [1998], Wurgler [2000]) or on financial market development (e.g., LaPorta et al. [1997], Demirguc-Kunt and Maksimovic [1998]), we focus on firm-level capital investment decisions. Second, we concentrate on accounting quality, a feature not examined in many prior studies (e.g., LaPorta et al. [1997], Demirguc-Kunt and Maksimovic [1998], Wurgler [2000]). In addition, we consider the differences both between countries and between firms within a country. Third, our tests do not limit capital market frictions to their effects on capital rationing exclusively (e.g., Fazzari et al. [1988]). Rather, we allow accounting quality to reduce either the lack or excess of cash. Finally, given the possibility that different sources of capital may substitute for each other, we do not limit our attention to any specific financing channel (e.g., Bhattacharya et al. [2003]) and instead focus on capital investment behavior.

\section{Hypothesis Development}

Tobin [1969] theorizes that capital investment is a function of the ratio between the stock-market valuation of existing real capital assets and their current replacement cost. Yoshikawa [1980], Hayashi [1982] and Abel [1983] reconcile this theory with the neoclassical interpretation. In this framework, the marginal $\mathrm{Q}$ ratio, $q$, is the driver of capital investment policy. For example, Hayashi [1982] summarizes the model by stating, 
"once $q$ is known $[\ldots]$, the firm can decide the optimal rate of investment though the knowledge of the installation function $\psi$ alone." He then proceeds to estimate this baseline model by regressing the investment rate on $q$. Fazzari et al. [1988] challenge this view and suggest that firms that are liquidity constrained (i.e., cannot externally finance their investments) need to rely more on their internally generated funds.

Hoshi et al. [1991] summarize two possible justifications for capital rationing. On the one hand, moral hazard models suggest that outside financing can dilute managements' ownership stakes, thereby exacerbating incentive problems that arise when managers control the firm but do not own it. This ex post incentive problem reduces the amount of capital supplied ex ante. On the other hand, Myers and Majluf [1984] propose an adverse selection model. They suggest that if managers are better informed than investors about a firm's prospects, they will try to sell overpriced securities. Rational investors will, in response, increase the cost of capital, thus decreasing the amount demanded. Therefore, in both cases, frictions operate to reduce the amount of external capital supplied to the firm. Firms that can generate cash internally are able to mitigate these effects, which causes capital investment to be correlated with the availability of internally generated funds.

There is presently a debate (see, for example, Fazzari et al. [2000] and Kaplan and Zingales $[1997,2000])$ as to whether higher investment-cash flow sensitivity necessarily implies that firms are more financially constrained. In this paper, we remain agnostic on this issue since the problem may not be a lack, but rather an excess of cash. Capital investment can be correlated with internally generated funds simply because managers do not return to investors excess cash coming from rents (and quasi rents) and other assets in 
place. Casual empiricism suggests the existence of such overinvestment by managers and several theoretical explanations have been proposed. For example, Jensen [1986] suggests that managers have incentives to grow their firms beyond their optimal size. ${ }^{4}$ Whereas external financing subjects managers to monitoring and disciplining by capital providers, "financing projects internally avoids this monitoring and the possibility the funds will be unavailable," thereby allowing managers to overinvest. Blanchard et al. [1994] provide empirical support for this view. They consider what managers do when they receive a cash windfall that does not change the investment opportunity set (i.e., Tobin's Q). In perfect financial markets, managers should return the money to the capital suppliers. Contrary to this expectation, Blanchard et al. [1994] find that managers tend to invest in unrelated projects that typically fail.

Notice that all of these imperfections are predicated by the existence of information asymmetry between managers and outside suppliers of capital. If managers could commit to revealing all of their private information, outsiders would not ration capital for fear of buying at an inflated price. Similarly, if higher quality accounting permitted perfect monitoring, no agency problem would arise (see, for example, Antle and Eppen [1985] for a formal model of this idea). We would then be back to the baseline neoclassical model and internally generated cash flows would play no role in investment decisions. Our main hypothesis is predicated on this idea:

Hypothesis 1: Higher quality accounting reduces the investment-cash flow sensitivity at the firm level.

\footnotetext{
${ }^{4}$ For simplicity, we use "empire building" as our main way to motivate overinvestment. However, there are other models leading to a similar pattern such as overconfidence (e.g., Heaton [2002]), the "quiet life" (Bertrand and Mullainathan [2003]) and reputation (e.g., Baker [2000]).
} 
We further predict, based on the reasoning above, that this effect should be stronger in economies where financing is largely provided through arm's-length transactions, for example, where the stock market is the dominant source of capital. On the other hand, in economies where creditors play a central role in financing, banks may be able to obtain information through alternate private channels (and thus mitigate adverse selection problems). They also may be in a better position to monitor the managers directly once the capital has been supplied (and thus mitigate the moral hazard). In this case, accounting quality should be less relevant to their decisions to supply capital and, as a result, we should observe a smaller effect of accounting quality on investment efficiency in credit-based economies. his leads to our second hypothesis:

Hypothesis 2: Higher quality accounting reduces the investment-cash flow sensitivity more in economies dominated by stock markets than in those dominated by creditors.

Notice that we do not form any prediction as to whether one type of economy is better than the other in mitigating frictions in the investment process.

\section{Cash flow sensitivity: Empirical setting}

\subsection{Overall approach.}

We employ both cross- and within-country tests, each with its own advantages. In the cross-country tests, average investment-cash flow sensitivities are estimated by country using firm-level data and then regressed on accounting quality and other variables of interest. This testing approach is likely to enhance the power of our tests by increasing both the cross-sectional variation and the magnitudes of financial frictions. It also enables us to consider the effects of institutional factors, such as creditor rights and 
legal origin, which cannot be easily studied in a single-country setting. As observed by Francis et al. [2005], "the United States is generally viewed as having a frictionless financial market with relatively easy access to external financing, and therefore it is not clear if U.S. findings necessarily generalize to countries with different financial or legal systems."

However, the cross-country approach also has some limitations. First, it is difficult to obtain sufficient time series data from multiple countries to estimate firmspecific parameters. Second, different institutional settings and accounting rules make it difficult to compare firm-based measures across countries. For example, since asset revaluation is permitted in some countries but not in others, plant, property and equipment and depreciation measures convey different meanings. To address these issues and to provide corroborating evidence that the hypothesized effect of accounting quality on investment efficiency operates within as well as across counties, we further examine two contrasting countries: the US and Japan. Both countries have large economies with ample sources of external financing. However, in the US, stock markets play a central role in providing capital, while in Japan, keiredtsu and banks are the major source of capital. As documented by Wurgler [2000], the ratio of stock market value to total credit market value is 0.64 for the US but only 0.15 in Japan. Our focus on the US and Japan allows us to assess whether the dominant form of financing influences the effect of accounting quality on investment decisions.

\subsection{Samples and data}

To enhance comparability with prior research, we utilize data from the same set of 34 countries examined by Bhattacharya et al. [2003]. For our cross-country tests, 
accounting and financial data are obtained from Compustat Global Vantage for the entire coverage period of the database (1993 to 2004). Accounting and financial data for the within-country tests are obtained for the US from COMPUSTAT and for Japan from the PACAP database (1975 to 2001). he longer time series for the within-country samples allow us to estimate firm-specific parameters and utilize them in panel specifications. We focus on industrial firms and, as is customary, exclude utilities and firms in the financial, real estate, insurance and public administration sectors. ${ }^{5}$ Our resulting sample includes only publicly traded companies with access to public sources of capital. As these firms also can potentially access alternate sources of capital including bank loans, governmental financing and private equity when public markets are inadequate, this provides a lower bound for the effects of accounting quality and other institutional features. Private firms with lesser access to capital and weaker outside monitoring would benefit relatively more from enhanced institutional features than would firms with more access to capital and stronger outside monitoring.

\subsection{Proxies for accounting quality.}

For our cross-country tests, we use four country-specific measures of accounting quality. Three of these measures are adapted from Bhattacharya et al. [2003] and a fourth from Bushman et al. [2004]. Earnings aggressiveness is based on the converse of conservatism as defined by Ball et al. [2000]. Following Ball et al. [2000] and Bhattacharya et al. [2003], we expect countries with more aggressive accounting practices to exhibit lower firm-level capital investment efficiency than countries with less aggressive accounting practices. Loss avoidance is the ratio of the number of firms with

\footnotetext{
${ }^{5} \mathrm{We}$ focus on industrial and commercial companies and, following prior studies, exclude US firms with SIC codes between 4900-4999, 6000-6999 and above 9000, and those trading as American Depository Receipts. We exclude Japanese firms with INDID codes starting with 05, 06 and 08.
} 
small positive earnings minus the number of firms with small negative earnings divided by the sum of the two. This proxy is derived from Burgstahler and Dichev [1997] and Degeorge et al. [1999] who employ a similar measure for US firms. Following Bhattacharya et al. [2003], we expect countries with greater loss avoidance to exhibit lower capital investment efficiency than countries with less loss avoidance. Earnings smoothing is based on the cross-sectional correlation between the change in accruals and the change in cash flows scaled by lagged total assets. Following Leuz et al. [2003] and Bhattacharya et al. [2003], we expect countries with a greater degree of earnings management to exhibit lower capital investment efficiency than countries with a smaller degree of earnings management. Following Bushman et al. [2004], Timeliness is based on the average ranking of "answers to the following interim reporting questions: frequency of reporting, count of disclosed items, and consolidation of interim reports." We expect countries with timelier reporting to exhibit higher capital investment efficiency than countries without timely reporting. Because we are agnostic regarding which dimension of accounting quality plays a more significant role, we aggregate the four accounting quality measures into a summary index (AQ). In order to combine them meaningfully, we first form binary specifications. We do so by creating four binary variables for earnings aggressiveness, loss avoidance, earnings smoothing and timeliness based on whether they have a better value than the median value in the cross-country sample. We then create $A Q$ by summing up these four binary variables. Combining the four measures into an index has the advantage of reducing the effects of measurement errors in the individual accounting quality measures. This index also is more comparable with the 
index variables for creditor and shareholder rights developed by LaPorta et al. [1997] introduced as control variables below. ${ }^{6}$

In our within-country tests for the US and Japan, we employ firm-specific accounting quality measures, $A Q_{\mathrm{FS}}$, reflecting the uncertainty in accruals following Dechow and Dichev [2002]. Francis et al. [2005] find that this measure of accounting quality is the most closely associated with their measure of the cost of capital. In Dechow and Dichev [2002], accruals quality is measured by the extent to which working capital accruals explain current-period, prior-period and future-period operating cash flow realizations. The unexplained portion of the variation in working capital accruals is an inverse measure of accruals quality (with a larger unexplained portion implying lower quality accounting). Details of the estimation procedure are provided in the appendix. We predict that higher quality accruals will be associated with higher capital investment efficiency especially in countries that rely on capital provided through arms-length transactions.

\subsection{Proxies for investment-cash flow sensitivity.}

We use two different but comparable procedures to measure investment-cash flow sensitivity in the cross-country and within-country tests. In the cross-country tests, we mirror the prior literature (e.g., Fazzari et al. [1988], Hoshi et al. [1991]) by estimating investment-cash flow sensitivities after controlling for investment opportunities using Tobin's Q (proxied by the market-to-book equity ratio, MTB). Given the heterogeneity of our cross-country sample, outliers could induce non-linear relations. A standard approach

\footnotetext{
${ }^{6} A Q$ takes values between 0 and 4 . Below, we also control for financial disclosure as measured by an index created by the Center for International Financial Analysis and Research (CIFAR). The CIFAR index can potentially take values between zero and one hundred. To make $A Q$ and CIFAR more comparable, we also normalize CIFAR by forming a variable that takes a value between zero and four based on quintiles of the distribution of CIFAR. Our results (untabulated) are not affected by this transformation.
} 
to alleviating this problem is to take the log of the variables, which we apply to marketto-book ratios. However, operating cash flows and investments often have negative values for which a $\log$ transformation is not defined. For them, we use an arctangent transformation that in effect "logs negative values." The following model is estimated (using firm fixed effects) for each country:

$I_{i, t} / K_{i, t-1}=\beta_{0}^{\mathrm{i}}+\beta_{1} O C F_{i, t} / K_{i, t-1}+\beta_{2} M T B_{i, t}+\varepsilon_{i, t}$

where $I_{i, t} / K_{i, t-1}$ is capital investment scaled by the beginning-of-period capital for firm $i$ in period $t, O C F_{i, t}$ is the operating cash flow, $\beta_{1}$ is our measure of investment-cash flow sensitivity, $\varepsilon_{i, t}$ is a normally distributed error term with a mean of zero, and it represents usual idiosyncratic errors.

This specification has two appealing features. First, it does not require a long time series for each firm to estimate the parameters, which allows us to use pooled crosssectional data to estimate an average investment-cash flow sensitivity for each country. This feature is important because Compustat Global Vantage contains a maximum of only 11 years of data. Second, this specification has been extensively used in the prior literature. However, it relies on $M T B$ to proxy for Q. To the extent that $M T B$ does not fully capture investment opportunities, cash flows may pick up measurement errors that are correlated across countries with accounting quality.

We address this concern in several ways. In our cross-country tests, we include future cash flows (Alti [2003]) and we use an instrumental variables approach in some specifications. In our within-country tests, we use two databases, COMPUSTAT for the

\footnotetext{
${ }^{7}$ The arctangent function is approximately linear over the range $[-1 ; 1]$. In cases where the absolute value of investment or cash flows is less than net fixed assets, the data are changed little by the transformation. However, when the absolute values of these scaled variables increase beyond 1, the transformed value is bounded by $\pi / 2$. This transformation provides a convenient way of winsorising the data.
} 
US and PACAP for Japan, which provide longer time series. This allows us to use an alternate test that does not rely on estimating Q. By doing so, we have a natural robustness check for our cross-country estimations. We proxy for cash flow sensitivity of investment (CFSI) using the measure recently proposed by Hovakimian and Hovakimian [2005]. $C F S I_{0}$ is measured as the difference between the cash-flow-weighted time-series average investment (CFWAI) of a firm and its un-weighted arithmetic time-series average investment $(A I)$ :

$$
\operatorname{CFSI}_{0, i, t}=C F W A I_{0, i, t}-A I_{i, t}=1 / n \sum_{s=1}^{t}\left[\left(C F_{i, s} /\left(\sum_{s=1}^{t} C F_{i, s}\right)\right) * I_{i, s}\right]-1 / n \sum_{s=1}^{t} I_{i, s}
$$

where $C F$ is a firm's cash flow, $I$ is the firm's investments (where both are scaled by beginning-of-period net capital), and $n$ is the number of annual observations for firm $i^{8}$

The intuition behind this specification is that there should be no systematic difference between the weighted and un-weighted average investments for firms whose investment decisions are not affected by their available cash flows. On the other hand, the value of CFSI should be higher for firms that tend to invest more in years with relatively high cash flows and less in years with relatively low cash flows. Unlike the measure of cash flow sensitivity in Equation (1), we do not have to estimate a regression coefficient and, therefore, we can avoid the associated econometric estimation issues.

\subsection{Estimation procedures}

Our cross-country tests regress the 34 investment-cash flow sensitivities from Equation (1) on our measure of accounting quality, other institutional features (disclosure quality, creditor rights, shareholder rights, judicial efficiency and legal origin), and

\footnotetext{
${ }^{8}$ Variable definitions are detailed in the Appendix.
} 
control variables such as the gross domestic product $(G D P)$, the average tangibility of firm assets, and firm size, which are all standard in the literature (see Appendix for variable definitions and estimation details). In the US within-country tests, we also control for auditing quality and analyst coverage as well as other control variables suggested by Hovakimian and Hovakimian [2005] and described in the Appendix. In both the US and Japan within-country tests, accounting quality, investment-cash flow sensitivity and control variables are estimated using ten-year rolling windows. Standard errors are corrected for heteroskedasticity and for clustering of observations by firm.

\section{Cash flow sensitivity: Empirical results.}

\subsection{Cash flow sensitivities and between countries differences}

Table 1 presents correlations among variables examined in the cross-country tests. Most correlations are reasonably small, suggesting that multicollinearity is not a significant concern. In particular, the correlation between $A Q$ and $C I F A R$ is only 0.13 , suggesting that these two variables capture two related but differing constructs. However, shareholder rights $(S R)$ is highly correlated with both $A Q$ and CIFAR, as is legal origin ( $L O)$ with $A Q, C I F A R, S R$, and $C R$. We take these high correlations into consideration in our later tests.

Table 2 presents tests of our first hypothesis by regressing investment-cash flow sensitivities at the country level from Equation (1) on accounting quality $(A Q)$ and other variables as described above. We report several specifications. In column 1, we enter only $A Q$. In columns 2 and 3, we control for other institutional features. Column 2 excludes $L O$, out of the concern that this variable is highly correlated with several other features. Finally, column 4 introduces controls for economy-wide factors. Results are 
consistent with our predictions. They indicate significant negative relations between $A Q$ and the cash flow sensitivity of investment. When we turn our attention to the other institutional features (CIFAR, JE, $C R, S R$, and $L O$ ), we see that while most are associated with lower investment-cash flow sensitivity, only CIFAR and $C R$ are consistently significant at conventional levels. This may be explained by a lack of power due to small sample size and it is not entirely unexpected given related findings in prior studies (e.g., DeFond and Hung [2004], Bushman et al. [2004]). ${ }^{9}$ Among the economic control variables, size has the strongest effect. Our results also appear to be economically significant, with the specification including all institutional factors (column 5) explaining 44 percent of the variation across countries in investment-cash flow sensitivity. $A Q$ alone explains 14 percent of the variation (column 1).

As a robustness check, we also employ a "direct" estimation procedure that examines firm-year observations (untabulated). Specifically, we interact $A Q$ with $O C F$ in Equation (1) (we also include $A Q$ in this specification). An advantage of this approach is that countries with larger economies comprise a larger share of the sample, so our sample is more representative of real economic activity. To prevent bias from measurement errors in Tobin's Q from driving our results, we estimate the model using a two-stage least squares (2SLS) procedure, whereby $M T B_{i, t}$ is instrumented by $M T B_{i, t-2}$ and Kint $_{i, t-3}$, lagged two and three periods, respectively, where Kint is the capital intensity defined as the ratio of net fixed assets to sales. Specification tests indicate that our instruments are both relevant and valid. We also apply ordinary least squares (OLS) techniques to ensure that our results do not hinge on a particular 2SLS specification. Standard errors in our

\footnotetext{
${ }^{9}$ DeFond and Hung [2004] report that international variations in shareholder rights do not affect CEO turnover. Bushman et al. [2004] find no relation between legal origin and their measure of financial transparency.
} 
pooled 2SLS specifications are adjusted for unspecified heteroskedasticity and serialcorrelation using a two-step efficient generalized method of moments (GMM) estimator (Hayashi [2000]). ${ }^{10}$ Results are consistent with our results from the indirect specification. The $\mathrm{z}$ - (or $\mathrm{t}-$ ) statistics range from -3.81 to -9.98 for the interaction between cash flows and our accounting quality index, and from -4.71 to -13.08 for the interaction with CIFAR. As expected, the $\mathrm{z}$-(or t-) statistics are positive and range from 8.37 to 28.13 for cash flows. Finally, Alti [2003] suggests that there could be cash flow sensitivity even in an economy without frictions, because contemporaneous cash flows may better reflect information about short-term profitability than would the market-to-book equity ratio $(M T B)$. To control for this possible effect, we add operating cash flow $(O C F)$ at time $t+1$ and $t+2$ (scaled by fixed assets) or the difference in operating cash flows. Although this specification reduces the sample size (since we need two future years to estimate future profitability), results are qualitatively similar. Thus, our cross-country tests support the first hypothesis that higher-quality accounting reduces investment-cash flow sensitivity at the firm level.

Our second hypothesis predicts that higher quality accounting should reduce investment-cash flow sensitivity more in economies dominated by stock markets than in those dominated by creditors. To test this prediction, we partition our cross-country sample based on whether the ratio of stock market value to credit market value in the country is above or below the median in the sample. Consistent with our hypothesis, accounting quality is statistically significant in the sub-sample of equity-based economies

\footnotetext{
${ }^{10}$ Alternatively, we remove the year dummies and allow for clustering of observations by year to control for cross-correlation in the error term. Untabulated results are qualitatively similar.
} 
(the $t$-statistic equals -2.06) but less than significant at conventional levels in the creditbased economies (the $t$-statistic equals -1.25$){ }^{11}$

\subsection{Cash flow sensitivities and within-country differences: the US}

Results for the US within-country tests reported in Table 3 are consistent with those for the international cross-sectional tests above. Column 1 reports the results for our panel specification where $\mathrm{CFSI}_{0}$ is the dependent variable and $A Q_{F S}$ is the only independent variable. In column 2, we introduce the set of control variables described above and in the Appendix. In column 3, following Hovakimian and Hovakimian [2005], we transform $C F S I_{0}$ into a binary variable that takes the value of one if $C F S I_{0}$ is greater than 0.05 and zero otherwise, then use a logit specification with firm fixed effects to estimate the coefficients. All of the specifications consistently indicate that $A Q_{F S}$ is associated with a reduction in the investment-cash flow sensitivity. This result is economically significant an increase of $A Q_{F S}$ by one standard deviation leads to a decrease of 30 percent in the average cash flow sensitivity. ${ }^{12}$ Thus, higher accounting quality is associated with higher investment efficiency even in the most liquid market in the presence of predominant public equity financing. Our results (untabulated) also hold under alternate specifications, for example, when we use boot-strapped standard errors, add year dummies, use observations from the last year only, control for the analyst coverage, and measure $C F S I_{0}$ using cash flows lagged by one year. Auditing quality (BigSix) and analyst coverage (AnalCov) are significantly negative in (untabulated) univariate regressions but these

\footnotetext{
${ }^{11}$ The magnitudes of the coefficients also are different (-0.15 for the equity-based sample and -0.09 for the credit-based sample). The small sample size prevents us from testing if these coefficient estimates differ significantly; pooling the two samples is also not feasible because of the high collinearity between the variable of interest in such a pooled sample. One should not necessarily conclude that accounting quality plays no role in credit-based economies for the same reason.

${ }^{12}$ We obtain this estimate by multiplying the value of the coefficient (1.62) by one standard deviation of $A Q_{F S}(0.014)$ and then dividing by the average $C F S I_{0}(0.076)$.
} 
variables become insignificant in some multivariate specifications. The other control variables generally have the expected signs and are generally consistent with Hovakimian and Hovakimian [2005]. For example, we would expect that larger, more profitable and more stable firms would be more transparent (see, among others, Lang and Lundholm [1993]). Hence, these firms should exhibit less investment-cash flow sensitivity than small and unprofitable and unstable firms. Consistent with these expectations, the coefficients on Size, ROA, Z-score, and CFO are negative, as expected, while the coefficients on $\sigma(C F O)$ and $M 2 B$ are positive.

\subsection{Cash flow sensitivities and within-country differences: Japan}

Untabulated results for the Japan within-country tests indicate that, contrary to the US results, there is no statistically significant negative relation between accounting quality and investment-cash flow sensitivity. Although the Japanese sample size is smaller than the US sample size (approximately 15,000 observations versus 30,000 for the US), it is still sufficiently large to rule out statistical power as an explanation. This lack of statistical significance is consistent with our second hypothesis that accounting quality should have a smaller effect on investment efficiency in countries where bank financing and keiretsu are important sources of capital than in countries where equity is a dominant source of capital, because capital suppliers in credit-based economies have alternative avenues for reducing information asymmetry. ${ }^{13}$

\footnotetext{
${ }^{13}$ The mean and the standard deviation of the winsorized investment-cash flow sensitivity estimates are 0.03 and 0.13 , respectively, for Japanese firms versus 0.07 and 0.20 , respectively, for US firms. This suggests that homogeneity does not explain the Japanese results.
} 


\section{Summary and Conclusion}

This study examines how accounting quality relates to firm-level capital investment efficiency. We consider several measures of accounting quality derived from prior research and two different methods for estimating investment-cash flow sensitivities. Our first hypothesis captures the intuition that higher quality accounting should enhance investment efficiency by reducing information asymmetry between managers and outside suppliers of capital. As argued in prior studies, information asymmetry can generate liquidity constraints (for example, as investors ration capital to protect themselves against adverse selection) or excess cash (for example, when it is difficult for owner-principals to monitor spending by manager-agents). Both situations generate inefficiencies in the investment process that accounting quality should mitigate. Our test results are consistent with this prediction both across and within countries under numerous alternative specifications. We find that the link between internally generated cash flows and investment is weaker when accounting quality is high. However, our tests do not address whether higher quality accounting operates primarily to mitigate the effect of a lack of cash or of its excess. This is a question we leave to future research.

Our second hypothesis is that the effect of higher quality accounting on investment-cash flow sensitivity should be stronger in economies where financing is largely provided through arm's length transactions, for example, where stock markets are dominant sources of capital. In contrast, in countries where creditors provide more capital, banks may be able to obtain information through alternative private channels and may be better positioned to monitor managers directly once capital is supplied. Thus, we predict a stronger (weaker) relation between accounting quality and capital investment 
efficiency in countries with predominant equity (bank) financing of firm-level capital investment. Our test results support this second hypothesis both across and within countries. Overall, our findings lend support to the argument that accounting quality is an institutional feature available to policy makers that enhances investment efficiency by mitigating investment-cash flow sensitivity, and that this effect is stronger under conditions where capital is provided through arms-length transactions. 


\section{References}

Abel, A. B., 1983. Optimal investment under uncertainty. American Economic Review 73(1): 228-233.

Alti, A. 2003. How sensitive is investment to cash flow when financing is frictionless? Journal of Finance 63(2): 707-722.

Antle, R., and G. Eppen, 1985. Capital rationing, and organizational slack in capital budgeting. Management Science 31(2): 163-174.

Bagehot, W. 1873. Lombard Street: A Description of the Money Market. Irwin (1962).

Baker, M., 2000. Career concerns, and staged investment. Working paper, Harvard University.

Ball, Ray, S.P. Kothari, and A. Robin, 2000. The effect of international institutional factors on properties of accounting earnings. Journal of Accounting and Economics 29: $1-51$.

Beck, T., R. Levine, and N. Loayza. 2000. Finance and the source of growth. Journal of Monetary Economics 46: 31-77.

Bertrand, M., and S. Mullainathan. 2003. Enjoying the Quiet Life? Corporate governance and managerial preferences. Journal of Political Economy 111(5): 1043-1075.

Bhattacharya, U., H. Daouk, and M. Welker, 2003. The world price of earnings opacity. The Accounting Review 78(3): 641-678.

Blanchard, O., F. Lopez-de-Silanez, and A. Shleifer, 1994. What do firms do with cash windfalls? Journal of Financial Economics 36(3): 337-360. 
Burgstahler, D., and I. Dichev. 1997. Earnings management to avoid earnings decreases and losses. Journal of Accounting and Economics (24): 99-126.

Bushman, R., J. Piotroski, and A. Smith. 2004. What determines corporate transparency? Journal of Accounting Research 42(2): 207-252.

Bushman, R., A, Smith, and F. Zhang. 2005. Investment-cash flow sensitivities are really capital investment-working capital investment sensitivities. Working paper, University of North Carolina.

Claessens, S., S. Djankov, and L. H. P. Lang. 2000. The separation of ownership and control in East Asian corporations. Journal of Financial Economics 58(1): 81-112.

Cobb, C., and P. Douglas. 1928. A theory of production. American Economic Review 8(1): 139-65.

Dechow, P., and I. Dichev. 2002. The quality of accruals and earnings: The role of accrual estimation errors. The Accounting Review 77 Supplement: 35-59.

DeFond, M., and M. Hung, 2004. Investor protection and corporate governance: Evidence from worldwide CEO turnover. Journal of Accounting Research 42(2): 269312.

Degeorge, F., J. Patel, and R. Zeckhauser, 1999. Earnings management to exceed thresholds. Journal of Business 72(1): 1-33.

Demirguc-Kunt, A., and V. Maksimovic. 1998. Law, finance, and firm growth. Journal of Finance 53: 2107-37.

Demirguc-Kunt, A., and V. Maksimovic. 2002. Funding growth in bank-based and market-based financial systems: evidence from firm-level data. Journal of Financial Economics 65(3): 337-63. 
Fazzari, Steven, R. G. Hubbard, and B. Petersen. 1988. Investment and finance reconsidered. Brookings Papers on Economics Activity: 141-195.

2000. Investment-cash flow sensitivities are not useful: a comment on Kaplan and Zingales. The Quarterly Journal of Economics 115(2): 695-705.

Francis, J., I. Khurana, and R. Pereira. 2005. Global evidence on incentives for voluntary accounting disclosures and the effect on cost of capital. Forthcoming, The Accounting Review.

Gorton, G., and F. Schmid. 2000. Universal banking and the performance of German firms. Journal of Financial Economics 20(1): 29-80.

Hayashi, F. 1982. Tobin's Marginal $q$ and Average $q$ : A Neoclassical Interpretation. Econometrica 50(1): 213-224.

2000. Econometrics. Princeton, Princeton University Press.

Healy, P., and K. Palepu, 2001. Information asymmetry, corporate disclosure, and the capital markets: A review of the empirical disclosure literature. Journal of Accounting and Economics 31(1-3): 405-440.

Heaton, J. 2002. Managerial optimism and corporate finance. Financial Management 31(2): 33-45.

Hovakimian, A., and G. Hovakimian. 2005. Cash flow sensitivity of investment. Working paper, City University of New York. 
Hoshi, T., A. Kashyap, and D. Scharfstein. 1991. Corporate structure, liquidity and investment: Evidence from Japanese industrial groups. The Quarterly Journal of Economics 106(1): 33-60.

Hubbard, R. G. 1998. Capital-market imperfections and investment. Journal of Economic Literature 36(1): 193-225.

Jensen, Michael. 1986. Agency costs of free cash flow, corporate finance, and takeovers. American Economic Review 76(2): 323-329.

Kaplan, S., and L. Zingales. 1997. Do financing constraints explain why investment is correlated with cash-flows. The Quarterly Journal of Economics 112(2): 169-215.

Kaplan, S., and L. Zingales. 2000. Investment-cash flow sensitivities are not valid measures of financing constraints. The Quarterly Journal of Economics 112(2): 707-712.

King, R., and R. Levine. 1993. Finance and growth: Schumpeter might be right. The Quarterly Journal of Economics 108(3): 717-737.

La Porta, R., F. Lopez-De-Silanes, A. Shleifer, and R. Vishny. 1997. Legal determinants of external finance. Journal of Finance 52(3): 1131-1150.

Lang, M., and R. Lundholm. 1993. Cross-sectional determinants of analysts' ratings of corporate disclosures. Journal of Accounting Research 31(2) (Autumn): 246-271.

Leuz, C., D. Nanda, and P. Wysocki. 2003. Earnings management and institutional factors: An international comparison. Journal of Financial Economics 69(3): 101-122.

Morck, R., A. Shleifer, and R. Vishny. 1990. The stock market and investment: Is the market a sideshow? Brookings Papers on Economic Activity 1: 157-215. 
Modigliani, F., and M. Miller. 1958. The Cost of capital, corporation finance, and the theory of investment. American Economic Review 48: 261-297.

Myers, S. 1984. The capital structure puzzle. Journal of Finance 39(3): 575-592.

Myers, S., and N. Majluf. 1984. Corporate financing and investment decisions when firms have information that investors do not have. Journal of Financial Economics 13(2): 187-221.

Rajan, R., and L. Zingales. 1998. Financial dependence and growth. American Economic Review 88: 559-586.

2000. The great reversals: The politics of financial development in the $20^{\text {th }}$ Century. OECD Working Paper.

Rousseau, P., and P. Wachtel. 1998. Financial intermediation and economic performance: Historical evidence from five industrialized countries. Journal of Money, Credit and Banking 30(4): 657-78.

Schwartz, R. 1997. Legal regimes, audit quality and investment. The Accounting Review 72(3): 385-406.

Tobin, J. 1969. A general equilibrium approach monetary theory. Journal of Money, Credit and Banking 1: 15-29.

Yoshikawa, H. 1980. On the " $q$ " theory of investment. American Economic Review 70(4): 739-43.

Whited, T., 1992. Debt, liquidity constraints and corporate investment: Evidence from panel data. Journal of Finance 47: 1425-1460. 
World Bank. 2003. World Bank Indicators. Washington, D.C.

Wugler, J. 2000. Financial markets and the allocation of capital. Journal of Financial Economics 58: 187-214. 


\section{Appendix: Details of Variable Estimation}

1) Accounting quality.

Cross-country sample

We create $A Q$ by summing binary measures of four variables adapted from Bhattacharya et al. [2003] and Bushman et al. [2004] as described in Section 4.3 above.

\section{US sample}

We first estimate the following model:

$$
T C A^{1}{ }_{j, t}=\varphi_{0, j}+\varphi_{1, j} C F O_{j, t-1}+\varphi_{2, j} C F O_{j, t}+\varphi_{3, j} C F O_{j, t+1}+u_{j, t}
$$

where $T C A_{j, t}=\Delta C A_{j, t}-\Delta C L_{j, t}-\Delta C a s h_{j, t}+\Delta S T D E B T_{j, t}=$ total current accruals in year $t$, $C F O_{j, t}=N I B E_{j, t}-T A_{j, t}=$ firm $j$ 's cash flow from operations in year $t, N I B E_{j, t}=$ firm $j$ 's net income before extraordinary items (Compustat \#18) in year $t, T A_{j, t}=\left(\Delta C A_{j, t}-\Delta C L_{j, t}-\right.$ $\left.\triangle \operatorname{Cash}_{j, t}+\triangle S T D E B T_{j, t}-D E P N_{j, t}\right)=$ firm $j$ 's total accruals in year $t, \Delta C A_{j, t}=$ firm $j$ 's change in current assets (Compustat \#4) between year $t-1$ and year $t, \Delta C L_{j, t}=$ firm $j$ 's change in current liabilities (Compustat \#5) between year $t-1$ and year $t, \Delta \operatorname{Cash}_{j, t}=$ firm $j$ 's change in cash (Compustat \#1) between year $t$ - 1 and year $t, \Delta S T D E B T_{j, t}=$ firm $j$ 's change in debt in current liabilities (Compustat \#34) between year $t$ - 1 and year $t, D E P N_{j, t}$ $=$ firm $j$ 's depreciation and amortization expense (Compustat \#14) in year $t$. We multiply the variance by minus one, so that a higher value of $A Q$ corresponds to higher accounting quality.

In addition, we follow Francis et al. [2005] and use the model modified to include plant, property and equipment (PPE) and change in revenues (scaled by average assets). McNichols [2002] proposes this extension, arguing that the change in sales revenue and 
PPE are important in forming expectations about current accruals, over and above the effects of operating cash flows. She shows that adding these variables to the crosssectional Dechow and Dichev [2002] regression significantly increases its explanatory power, thus reducing measurement error. However, the drawback of using this specification for our purpose is that it may include a mechanical link with our right-hand side variables by including capital investment in the regression. As a robustness check, we estimate a second model:

$T C A^{2}{ }_{j, t}=\psi_{0, j}+\psi_{1, j} C F O_{j, t-1}+\psi_{2, j} C F O_{j, t}+\psi_{3, j} C F O_{j, t+1}+\psi_{4, j} \Delta R e v_{j, t}+\psi_{5, j} P P E_{j, t}+\eta_{j, t}$

where $\Delta \operatorname{Rev}_{j, t}=$ firm $j$ 's change in revenues (Compustat \#12) between year $t-1$ and year $t$, $P P E_{j, t}=$ firm $j$ 's gross value of PPE (Compustat \#7) in year $t$. To conserve space, we only tabulate the results from the first specification but results are very similar when we use the second one.

\section{Japanese sample}

We follow a similar approach in our Japanese sample. Specifically, we use the following items from PACAP: INC9 and INC8 for NIBE; BAL6 for $C A$; BAL13 for $C L$; BAL1 for Cash; JAF34 for STDEBT; JAF74 for DEPN; INC1 for Rev; and the sum of JAF16, JAF17, JAF18, JAF19, JAF20 and JAF21 for $P P E$.

2) Variable I for cash flow sensitivities.

\section{Cross-country sample}

To calculate investment-cash flow sensitivities in the cross-country sample, we estimate the following model: 


$$
I_{i, t} / K_{i, t-1}=\beta_{0}^{i}+\beta_{1} O C F_{i, t} / K_{i, t-1}+\beta_{2} M T B_{i, t}+\varepsilon_{i, t}
$$

where $I_{i, t}$ is the investment in fixed assets for firm $i$ in year $t$, defined as the change in net fixed assets (Global Vantage data76) plus depreciation expense (data11). $K_{i, t-1}$ is the total fixed assets for firm $i$ in year $t-1 . M T B_{\mathrm{i}, \mathrm{t}}$, our proxy for the $\mathrm{Q}$ ratio, is measured as the ratio of the sum of the market value of equity (data13 multiplied by data3) and the book value of debt divided (data106, data136 and data137 minus data138 and data139) by the book value of total asset (data89). One advantage of using the (quasi) market value of assets instead of their book value is that we do not drop from our sample firms with a negative equity book value. Consistent with prior literature (e.g., Hoshi et al. [1991]), Q is calculated at the beginning of the period. Following previous studies, ${ }^{14} O C F_{\mathrm{i}, \mathrm{t}}$ is calculated as the sum of net income (data32) and depreciation expense (data11).

\section{US Sample}

To calculate the cash flow sensitivity in our within-country samples, we estimate the model proposed by Hovakimian and Hovakimian [1985]:

$$
\begin{aligned}
\operatorname{CFSI}_{0, i, t} & =C F W A I_{0, i, t}-A I_{i, t} \\
& =1 / n \Sigma_{s=1} l^{t}\left[\left(C F_{i, s} /\left(\Sigma_{s=1}^{t} C F_{i, s}\right)\right) * I_{i, s}\right]-1 / n \sum_{s=l}^{t} I_{i, s}
\end{aligned}
$$

where $n$ is the number of annual observations for firm $i$ and $t$ indicates the time period. $I$ denotes investment, defined as capital expenditures (Compustat Item 128) divided by the beginning-of-period net capital. $C F$ denotes cash flow and is defined as the sum of the income before extraordinary items (Compustat Item 18) and depreciation and

\footnotetext{
${ }^{14}$ See, among others, Morck et al. [1990], Hoshi et al. [1991], Whited [1992], Kaplan and Zingales [1997, 2000], Hovakimian and Hovakimian [2005]. We purposely do not correct our estimates of cash flows for any "working capital" effect for two reasons. First, we want to be consistent with prior literature on cash flow sensitivity of investment. Second, some firms lack the relevant information in our international database; thus, correcting our estimates of cash flows would introduce a selection bias. Our approach also has been used in prior international studies (e.g., Ball et al. [2000]).
} 
amortization (Item 14), divided by the beginning-of-period net capital (Item 8). As an untabulated robustness check, we also consider a cash flow measure from Bushman et al. [2005] that excludes working capital accruals. Our results still hold. To avoid negative and extreme weighted values, we follow Hovakimian and Hovakimian [2005] and set the negative cash flows to zero. The variable is estimated using a ten-year rolling window. This specification does not require the estimation of Q. By doing so, we have a natural robustness check for the efficiency of our various statistical corrections in our crosscountry sample.

In addition, since investment and cash flow are measured over an annual period, their exact timings may not coincide. In order to account for the possibility that investment may be financed with cash flows from the previous fiscal year, we also estimate $C F S I$ based on $O C F$, which is lagged relative to investment:

$$
\begin{aligned}
& C F S I_{-1, \mathrm{i}, \mathrm{t}}=C F W A I_{-1, \mathrm{i}, \mathrm{t}}-A I_{i, t} \\
& \quad=1 / n \Sigma_{\mathrm{s}=1}^{\mathrm{t}}\left[\left(C F_{i, s-1} /\left(\Sigma_{s=1}^{t} C F_{i, s-1}\right)\right) * I_{i, s}\right]-1 / n \Sigma_{s=1}^{t} I_{i, s}
\end{aligned}
$$

Results (untabulated) are not affected by using this alternative definition.

\section{Japanese sample}

We follow a similar approach in our Japanese sample. Specifically, we use the following items from PACAP: change in PPE plus JAF74 scaled by beginning period PPE for $I$ and NIBE plus JAF74, divided by the beginning-of-period net PPE for $C F$.

3) Control variables in the cash flow sensitivity regressions.

Cross-country sample

The institutional feature of primary interest is accounting quality, but we also consider financial disclosure, creditor rights $(C R)$, shareholder rights $(S R)$, judicial 
efficiency $(J E)$ and legal origin $(L O)$. As in many previous studies (e.g., Battacharya et al. [2003]), we measure financial disclosure quality using an index created by the Center for International Financial Analysis and Research (CIFAR). $C R$ and $S R$ are based on the summary measures of creditor rights $(\mathrm{Cr} 5)$ and shareholder rights $(\mathrm{Sr} 8)$ obtained from $\mathrm{La}$ Porta et al. [1997]. Our measure of judicial efficiency, $J E$, is the sum of the five proxies for judicial efficiency $(R l 1-R l 5)$ found in La Porta et al. [1997]. LO takes the value of one if the country has a legal origin rooted in the Common law tradition (zero otherwise). We also control for economic characteristics: $\log (G D P /$ Capita $)$ is gross domestic product per capita as reported by the World Bank [2003]; K-Intensity is the average capital intensity for a given country defined as the ratio of net fixed assets to sales; Size is the average firm size in the country measured as the log of the sum of the market value of equity and the book value of debt.

\section{US sample}

As proposed by Hovakimian and Hovakimian [2005], we control for size (log of Compustat item 6), market-to-book ratio (item 6 plus the product of items 25 and 199 minus item 60 and item 35, scaled by item 6), ROA (a measure of profitability calculated as the ratio of Compustat item 170 divided by item 6), dividend payout ratio (a dummy variable that takes the value of one if item 21 or 127 is greater than zero, zero otherwise), leverage (item 9 scaled by data 9 plus the product of items 25 and 199), Z-score (a measure of bankruptcy risk defined as 3.3 times item $170+$ item $12+$ one fourth of item 36 plus one half of the difference between item 4 and item 5 , scaled by item 6 ), the standard error of $C F O$, tangibility (a measure of bankruptcy cost defined as the ratio of item 8 and item 6), and R\&D (a dummy variable that takes the value of one if item 46 is 
greater than zero, zero otherwise). In addition, we include two measures of financial slack, CFOsale (the ratio of $C F O$ divided by item 12) and Slack (the ratio of item 1 and item 8). Finally, we control for auditing quality by including BigSix, a dummy variable taking the value of one if the firm is audited by a Big Six auditor (data \# 159 between 10 and 89), zero otherwise. Generally, we expect bigger firms, with higher and more stable cash flows, more tangible assets and fewer investment opportunities to be less sensitive to internally generated cash flows. We also control for analyst coverage in an untabulated robustness check. To measure analyst coverage, we use data obtained from the $\mathrm{I} / \mathrm{B} / \mathrm{E} / \mathrm{S}$ Historical Summary File. We use AnalCov, the log of the number of analysts (plus one since the $\log$ of zero is not defined) reported by IBES as covering the firm, as our proxy for analyst coverage. For each year, we set the number of analysts following a firm as the maximum number of analysts who make annual earnings forecasts in any month over a twelve-month period. We assume that firms not covered by $\mathrm{I} / \mathrm{B} / \mathrm{E} / \mathrm{S}$ are not covered by analysts.

\section{Japanese sample}

We follow a similar approach in our Japanese sample. Specifically, we use the following items from PACAP: log of BAL9 for size; the sum of BAL9 and market value minus BAL21 scaled by BAL9 for market-to-book ratio; the sum of INC9, INC8 and INC7 scaled by BAL9 for ROA; MKT1 for calculating dividend payout ratio; the ratio of BAL14 divided by market value and BAL14 for leverage; 3.3 times the sum of INC9, INC8 and INC7 plus INC1 plus 0.25 time BAL20 plus 0.5 times the difference between BAL6 and BAL13, scaled by BAL9 for Z-score; the ratio CFO over INC1 for tangibility; 
the ratio of CFO divided by INCI for CFOsale; and the ratio of BAL1 scaled by the sum of JAF16 through 21 and 23 for Slack. 


\section{Table 1: Correlations among summary measures ${ }^{1}$}

\begin{tabular}{|c|c|c|c|c|c|}
\hline & $A Q$ & CIFAR & $C R$ & $S R$ & $J E$ \\
\hline CIFAR & $\begin{array}{c}0.13 \\
(0.48)\end{array}$ & & & & \\
\hline$C R$ & $\begin{array}{c}-0.17 \\
(0.33)\end{array}$ & $\begin{array}{c}0.04 \\
(0.83)\end{array}$ & & & \\
\hline$S R$ & $\begin{array}{c}0.31 \\
(0.08)\end{array}$ & $\begin{array}{c}0.39 \\
(0.03)\end{array}$ & $\begin{array}{c}0.22 \\
(0.20)\end{array}$ & & \\
\hline$J E$ & $\begin{array}{l}-0.16 \\
(0.37)\end{array}$ & $\begin{array}{c}0.44 \\
(0.01)\end{array}$ & $\begin{array}{c}-0.15 \\
(0.41)\end{array}$ & $\begin{array}{c}-0.08 \\
(0.66)\end{array}$ & \\
\hline$L O$ & $\begin{array}{c}0.27 \\
(0.12)\end{array}$ & $\begin{array}{c}0.35 \\
(0.04)\end{array}$ & $\begin{array}{c}0.38 \\
(0.03) \\
\end{array}$ & $\begin{array}{c}0.66 \\
(0.00) \\
\end{array}$ & $\begin{array}{c}-0.11 \\
(0.55) \\
\end{array}$ \\
\hline
\end{tabular}

${ }^{1} A Q$ is a measure of accounting transparency calculated as the sum of Earnings aggressiveness, Loss avoidance, Earnings smoothing (Bhattacharya et al. [2003]) and Timeliness (Bushman et al. [2004]). CIFAR is based on a disclosure index calculated by the Center for International Financial Analysis and Research. $C R$ is a summary measure for creditor rights (as reported by La Porta et al. [1997]). SR is a summary measure for shareholder rights (as reported in La Porta et al. [1997]). JE is a measure of judicial efficiency based on the five measures found in La Porta et al. [1997]. $L O$ is an indicator variable that takes the value of one if a country's legal system has as a Common law origin, zero otherwise (as reported by La Porta et al. [1997]). The $p$-values are reported in parentheses. 
Table 2: Investment-cash flow sensitivity - Cross-country sample ${ }^{1}$

\begin{tabular}{|c|c|c|c|c|c|}
\hline \multirow[t]{2}{*}{ Variable } & \multirow[t]{2}{*}{$\begin{array}{l}\text { Predicted } \\
\quad \text { Sign }\end{array}$} & \multicolumn{4}{|c|}{ Dependent Variable: Investment-cash flow sensitivity } \\
\hline & & $(1)$ & (2) & (3) & (4) \\
\hline \multirow[t]{2}{*}{ Intercept } & $(+)$ & 0.527 & 1.725 & 1.558 & 1.994 \\
\hline & & $(5.07)$ & (3.66) & $(3.12)$ & (3.69) \\
\hline \multirow[t]{2}{*}{$A Q_{i}$} & $(-)$ & -0.120 & -0.141 & -0.129 & -0.113 \\
\hline & & $(-2.74)$ & $(-2.63)$ & $(-2.40)$ & $(-2.01)$ \\
\hline \multirow[t]{2}{*}{ CIFAR } & $(-)$ & & -0.014 & -0.013 & -0.018 \\
\hline & & & $(-2.29)$ & $(-1.98)$ & $(-2.52)$ \\
\hline \multirow[t]{2}{*}{$J E_{i}$} & $(-)$ & & -0.008 & -0.010 & -0.016 \\
\hline & & & $(-0.63)$ & $(-0.81)$ & $(-1.19)$ \\
\hline \multirow[t]{2}{*}{$C R_{i}$} & $(-)$ & & -0.089 & -0.071 & -0.069 \\
\hline & & & $(-2.48)$ & $(-1.96)$ & $(-1.88)$ \\
\hline \multirow[t]{2}{*}{$S R_{i}$} & $(-)$ & & 0.038 & 0.056 & 0.075 \\
\hline & & & $(0.92)$ & $(1.24)$ & (1.52) \\
\hline \multirow[t]{2}{*}{$L O_{i}$} & $(-)$ & & & -0.126 & -0.207 \\
\hline & & & & $(-1.33)$ & $(-1.86)$ \\
\hline \multirow[t]{2}{*}{$\log (G D P /$ capita $)$} & $(-)$ & & & & -0.000 \\
\hline & & & & & $(-1.37)$ \\
\hline \multirow[t]{2}{*}{ K-Intensity } & $(-)$ & & & & 0.002 \\
\hline & & & & & $(0.06)$ \\
\hline \multirow[t]{2}{*}{ Size } & $(-)$ & & & & -0.030 \\
\hline & & & & & $(-3.39)$ \\
\hline $\begin{array}{l}\text { Number of } \\
\text { observations }\end{array}$ & & 34 & 33 & 33 & 33 \\
\hline$R$-square & & $13.96 \%$ & $42.05 \%$ & $43.94 \%$ & $55.32 \%$ \\
\hline
\end{tabular}

${ }^{1} A Q$ is a measure of accounting transparency calculated as the sum of Earnings aggressiveness, Loss avoidance, Earnings smoothing (Bhattacharya et al. [2003]) and Timeliness (Bushman et al. [2004]). CIFAR is based on a disclosure index calculated by the Center for International Financial Analysis and Research. $J E$ is a measure of judicial efficiency based on the five measures found in La Porta et al. [1997]. $C R$ is a summary measure for creditor rights (as reported by La Porta et al. [1997]). SR is a summary measure for shareholder rights (as reported by La Porta et al. [1997]). $L O$ is an indicator variable that takes the value of one if a country's legal system has as a Common law origin, zero otherwise (as reported by La Porta et al. [1997]). Log(GDP/Capita) is gross domestic product per capita. K-Intensity is the average capital intensity for a given country defined as the ratio of net fixed assets to sales. Size is the average firm size in the country. Regressions are estimated using ordinary least squares. The $t$-statistics with standard errors adjusted for heteroskedasticity are reported in parentheses. 
Table 3: Investment-cash flow sensitivity - US sample ${ }^{1}$

\begin{tabular}{|c|c|c|c|}
\hline \multirow[t]{2}{*}{ Variable } & \multicolumn{3}{|c|}{ Dependent Variable: Investment-cash flow sensitivity } \\
\hline & $(1)$ & (2) & (3) \\
\hline \multirow[t]{2}{*}{$A Q_{F S}$} & -2.48 & -1.624 & -27.57 \\
\hline & $(-9.17)$ & $(-6.24)$ & $(-10.26)$ \\
\hline \multirow[t]{2}{*}{ BigSix } & & -0.111 & -0.17 \\
\hline & & $(-2.41)$ & $(0.43)$ \\
\hline \multirow[t]{2}{*}{ LogAsset } & & -0.028 & -0.559 \\
\hline & & $(-6.85)$ & $(-9.48)$ \\
\hline \multirow[t]{2}{*}{ Mkt-to-Book } & & 0.048 & 1.257 \\
\hline & & $(5.92)$ & (11.76) \\
\hline \multirow[t]{2}{*}{$R O A$} & & -0.434 & -6.124 \\
\hline & & $(-3.92)$ & $(-5.88)$ \\
\hline \multirow[t]{2}{*}{$\sigma(C F O)$} & & 0.639 & 11.916 \\
\hline & & $(5.18)$ & (12.14) \\
\hline \multirow[t]{2}{*}{ Z-score } & & -0.029 & -0.401 \\
\hline & & $(-2.46)$ & $(-2.91)$ \\
\hline \multirow[t]{2}{*}{ Tangibility } & & 0.131 & 3.209 \\
\hline & & (3.18) & $(5.45)$ \\
\hline \multirow[t]{2}{*}{$R \& D$} & & 0.000 & -0.043 \\
\hline & & $(0.03)$ & $(-0.22)$ \\
\hline \multirow[t]{2}{*}{$K$-structure } & & -0.036 & 1.33 \\
\hline & & $(-1.09)$ & $(3.59)$ \\
\hline \multirow[t]{2}{*}{ Mean K-structure } & & 0.225 & 1.129 \\
\hline & & $(3.47)$ & $(1.03)$ \\
\hline \multirow[t]{2}{*}{ CFOsale } & & -13.717 & -48.145 \\
\hline & & $(-3.72)$ & $(-1.60)$ \\
\hline \multirow[t]{2}{*}{ Slack } & & 0.016 & 0.272 \\
\hline & & $(1.73)$ & $(5.03)$ \\
\hline \multirow[t]{2}{*}{ Dividend } & & 0.010 & 0.395 \\
\hline & & $(0.67)$ & $(2.64)$ \\
\hline Number of observations & 28,353 & 28,353 & 12,420 \\
\hline$R$-square & $68.24 \%$ & $70.10 \%$ & \\
\hline
\end{tabular}

${ }^{1}$ The dependent variable is a measure of cash flow sensitivity as defined by Hovakimian and Hovakimian [2005]. $A Q_{F S}$ is a measure of accounting quality as defined by Francis et al. [2005]. BigSix is a dummy variable that takes the value of one if the firm is audited by a Big Six auditor (data \# 159 between 10 and 89), zero otherwise. LogAsset is the log of Compustat item 6. Mkt-to-Book is item 6 plus the product of item 25 and 199 minus item 60 and item 35, scaled by item 6. ROA is a measure of profitability calculated as the ratio of Compustat item 170 divided by item $6 . \sigma(C F O)$ is the standard deviation of cash flows from 
operations. Z-score is a measure of bankruptcy risk defined as 3.3 times item $170+$ item $12+$ one fourth of item 36 plus one half of the difference between item 4 and item 5, scaled by item 6 . Tangibility is a measure of bankruptcy cost defined as the ratio of item 8 and item $6 . R \& D$ is a dummy variable that takes the value of one if item 46 is greater than zero, zero otherwise. $K$-structure is item 9 scaled by data 9 plus the product of item 25 and 199. Mean $K$-structure is the mean of $K$-structure at the industry level. Slack the ratio of item 1 and item 8. Dividend is a dummy variable that takes the value of one if item 21 or 127 is greater than zero, zero otherwise. Columns 1 and 2 are estimated using ordinary least squares. Column 3 is estimated using a logit specification. All specifications use firm fixed effects. The $t$-statistics are reported in parentheses. 